ORIGINAL ARTICLE

\title{
Effects of Diet and Exercise in Middle Aged Subjects with Impaired Glucose Tolerance
}

\author{
MM Haque ${ }^{1}$, M Shahjahan $^{2}$, MS Haque ${ }^{2}$, N Absar $^{3}$ \\ ${ }^{1}$ Rajshahi Diabetic Clinic, Rajshahi, Bangladesh \\ ${ }^{2}$ Dept of Biochemistry and Molecular Biology, University of Rajshahi, Rajshahi \\ ${ }^{3}$ Dept of Biochemistry and Biotechnology, University of Science and Technology, Chittagong
}

\begin{abstract}
Patients with impaired glucose tolerance (IGT) are now considered as being pre-diabetic, which indicates their relatively high risk for developing diabetes mellitus associated with abnormal metabolic syndrome and cardiovascular diseases. However, dietary modification and physical exercise may play a critical role in this respect. To determine the influence of dietary modification and physical exercise in subjects with impaired glucose tolerance in Bangladesh, thirty three newly detected otherwise healthy subjects with IGT, aged 30-63 years, were randomly selected to participate in a 12 weeks diet and exercise program. Substantial improvement in glucose tolerance was observed at the end of 12 weeks particularly in middle aged subjects (41-50 years). Mean fasting blood glucose and $2 \mathrm{hr}$ post load glucose value were reduced significantly. Glucose tolerance was reverted to normal in $66.7 \%$ of the participants, remained unchanged in $26.7 \%$ and deteriorated to diabetes in 6.7\%. Significant reduction in serum total cholesterol, LDL cholesterol along with mild deterioration in HDL cholesterol and increase in triglyceride values were observed. It was found that the principles of 'prudent diet' in combination with physical exercise are highly effective in improving glucose tolerance, lowering total cholesterol and LDL cholesterol in IGT subjects.

Key words: Impaired Glucose Tolerance, Prudent Diet, Physical Exercise, Blood Glucose Regulation, T2DM
\end{abstract}

\section{Introduction}

Diabetes mellitus represents one of the most prevalent chronic diseases worldwide, afflicting individuals in developed as well as in developing countries. The disease is characterized by metabolic abnormalities and long-term complications involving eyes, kidneys, nerves and blood vessels. Diabetes and its complications are major and increasing health problem in many parts of the world. The most frequent form type 2 diabetes (T2DM) which comprises $90-95 \%$ of all diabetes, leads to vascular complications that give rise to considerable morbidity and premature mortality. Thus, a policy of early detection and treatment, as opposed to prevention of T2DM might be less effective in prevention of micro-vascular complications.

Impaired glucose tolerance (IGT), a lesser degree of hyperglycemia represents an intermediate stage in the development of T2DM and is associated clinically with a higher prevalence of atherosclerotic vascular diseases ${ }^{1}$. Risk factors known to influence the rate of progression from IGT to diabetes include age, obesity, hyperinsulinemia and insulin resistance $^{2}$. Physical inactivity and high fat diet have also been found to predict IGT and T2DM ${ }^{3}$. Dietary change is part of most weight 
control programs, and calorie restriction decreases hyperglycemia dramatically ${ }^{4}$. Lowering fat content of the diet may aid in weight loss and may have other benefits. Since atherosclerosis is a major risk for both IGT and T2DM, many authoritative bodies have reviewed the dietary advice for diabetics largely bringing it into line with the 'prudent diets' being recommended to the general population to reduce the risk of arterial disease ${ }^{5}$. Where the prevailing pattern of food intake requires it, dietary fat should be limited to approximately $30 \%$ of total daily energy intake, and foods containing polyunsaturated vegetable oils should be substituted for those containing saturated fats. Protein should account for approximately $15-20 \%$ of the daily intake and carbohydrates rich in natural fiber should constitute the remaining food energy.

Planned physical activity, according to the age and physical status, is considered a useful part of treatment ${ }^{6}$. Exercise improves metabolism, and has been shown to enhance insulin action on target tissues and contribute to weight loss. Over the past decade, several studies ${ }^{7,8}$ have demonstrated significantly improved glycemic control in patients with T2DM treated with regular exercise. Thus, intervention in the form of dietary modification and physical exercise in individuals with impaired glucose tolerance (IGT) could significantly improve metabolic control, reduce the incidence of diabetes mellitus and thereby may have a major impact on the public health burden of diabetes in the near future. Therefore, it is desirable to evaluate the effectiveness of dietary modification and physical exercise in Bangladeshi IGT subjects to improve quality of life and maintain good metabolic control in IGT subjects in order to prevent or revert the progression to diabetes and associated complications.

\section{Materials and Methods}

\section{Subjects}

This study was conducted at a university and diabetic clinic after approval was received from the institutional review board and informed consent from the participants. One hundred and thirty seven persons (men 67 and women 70) with impaired glucose tolerance (IGT), registered at Rajshahi Diabetic Clinic, aged 3563 years, were recruited for the study and were questioned to obtain relevant information on the socio-demographic data. Of these individuals, 50 otherwise healthy subjects (i.e. apart from minor, unconnected ailments or mild hypertension) aged 35-63 years, were invited to participate in a 12 weeks diet and exercise intervention program. Thirty three subjects (men 17 and women 16) agreed to participate in the program and they were selected by the following criteria:

1. Subjects who met the revised criteria for IGT (FBS $<7.0 \mathrm{mmol} /$ and $2 \mathrm{~h} \mathrm{PG}>7.8 \mathrm{mmol} / \mathrm{L}$ but $<11.1 \mathrm{mmol} / \mathrm{L})$. 2. Middle aged men and women without evidence of coronary heart disease (CHD), stroke or other major illness. 3. Subjects taking drugs that may impair glucose tolerance at baseline or during the follow up period were excluded. With a dropout rate less than $10 \%$, the remaining subjects were 30 (men 16 and women 14).

\section{Baseline examination}

A baseline examination was conducted on each participant after a 10 to $12 \mathrm{hr}$ overnight fast. Height and weight of the participants were measured in light clothing and without shoes. BMI was calculated using the formula $\mathrm{BMI}=$ (weight in $\mathrm{kg}) /\left(\right.$ height in meter $\left.^{2}\right)$. After a fasting blood sample was taken, each subject ingested $75 \mathrm{~g}$ of glucose monohydrate dissolved in $300 \mathrm{ml}$ water within a 2 minute period. Blood glucose, total cholesterol, HDL cholesterol, LDL cholesterol, triglyceride were measured in fasting sample. Blood glucose was also measured in the sample obtained $2 \mathrm{hrs}$ after the glucose load.

\section{Interventions}

Appropriate dietary advice was given to the subjects and participants were encouraged to increase the amount of their leisure physical activities.

\section{Diet}

Participants with $\mathrm{BMI}<25 \mathrm{~kg} / \mathrm{m}^{2}$ were prescribed a 'prudent diet' containing $30 \mathrm{kcal} / \mathrm{kg}$ body weight. Subjects with BMI $>25 \mathrm{~kg} / \mathrm{m}^{2}$ 
Effects of Diet and Exercise in Middle Aged Subjects with IGT were encouraged to reduce their calorie intake so as to gradually lose weight at a rate of 0.5 to $1.0 \mathrm{~kg}$ per month until they achieved a BMI of $23 \mathrm{~kg} / \mathrm{m}^{2}$. The recommended proportion of calorie intake was $55-65 \%$ carbohydrate (preferably complex carbohydrate e.g., starches), $10-20 \%$ protein and $20-30 \%$ fat (increasing the ratio of polyunsaturated fat to saturated fat). The participants were encouraged to consume more food with high fiber content, (e.g., whole grains, fresh fruits, vegetables) and reduce the intake of simple sugars. Individual's goals were set for total calorie consumption, and daily quantities of cereals, vegetables, meat, milk, and oils. This was accomplished by providing a list to each individual of the recommended daily intake of commonly consumed foods and a substitution list to allow exchange within food groups. In addition, participants received an individual counseling by a physician.

\section{Exercise}

Participants were taught and encouraged to increase the amount of leisure physical activities. The rate of increase and type of exercise were recommended on participant's interest, age, past exercise patterns and fitness. Participants were encouraged to exercise at least two units per day and five days in each week. Appropriate indoor activities were suggested for winter. Physical activity was ascertained in minutes per day for major activities, such as walking, running, cycling, ball playing, aerobics, gardening and swimming etc. and converted to units per day as shown below.

Activities required for one unit of exercise:

\begin{tabular}{|c|c|c|}
\hline Intensity & Time (min) & Exercise \\
\hline Mild & 30 & $\begin{array}{l}\text { Slow walking shopping, House } \\
\text { cleaing, Gardening }\end{array}$ \\
\hline Moderate & 20 & $\begin{array}{l}\text { Faster walking, Walking down } \\
\text { stairs, Cycling, Doing heavy } \\
\text { Laundry }\end{array}$ \\
\hline Strenuous & 10 & $\begin{array}{l}\text { Slow running, climbing, sttairs, } \\
\text { Playing basket ball, tennins, } \\
\text { Swimming }\end{array}$ \\
\hline
\end{tabular}

\section{Blood sampling}

With all aseptic precautions, $5 \mathrm{ml}$ of venous blood was taken in a clean dry test tube and allowed to clot and then centrifuged at a speed $2500 \mathrm{rpm}$ for 5 minutes. Serum was separated within 30 minutes.

\section{Assay of serum metabolite}

Serum glucose was estimated by enzymaticcolorimetric (GOD-PAP) method ${ }^{9}$,Serum cholesterol was determined by enzymaticcolorimetric (CHOD-PAP) method ${ }^{10}$, and serum triglycerides were measured by enzymaticcolorimetric GPO-PAP method ${ }^{11}$. Serum HDL cholesterol was determined by phosphotungstate/magnesium method ${ }^{12}$. The value of the LDL cholesterol was calculated using Friedwald's formula.

\section{Statistical analysis}

Results of the experiments were expressed as mean and standard error of different groups. The differences between the mean values were evaluated by ANOVA followed by paired t-test using SPSS software.

\section{Results}

Sociodemographic characteristics of the participants

Mean \pm SE age (years) of the participants was $45 \pm 1.35$ with a range of $35-63$ years, nine participants $(30 \%)$ were within $35-40$ years while majority fifteen participants $(50 \%)$ aged 41-50 years and rest six participants (20\%) were above 50 (51-63) years (Table 1). 53.3\% of the total participants were male $(n=16)$ and $46.7 \%$ were female $(n=14)$ (Table 1$)$. Much diversity in education level was observed among the participants and is shown in Table 1 , where two peoples $(6.7 \%)$ were illiterate while primary, secondary and higher secondary educated peoples were 04 (13.4\%), $11(36.6 \%)$ and $06(20 \%)$ respectively. The graduate and postgraduate participants were 05 $(16.6 \%)$ and $02(6.7 \%)$ respectively. 
Bangladesh J Med Biochem 2014; 7(1)

Table-I: Distribution of the participants by age, sex and education

\begin{tabular}{lcc}
\hline Age (Yrs) & No. of participants & Percentage (\%) \\
\hline 3540 & 9 & 30 \\
$41-50$ & 15 & 50 \\
$51-63$ & 6 & 20 \\
Sex & & \\
Male & 16 & 53.3 \\
Female & 14 & 46.7 \\
Education & & \\
Illiterate & 2 & 6.7 \\
Primary & 4 & 13.4 \\
Secondary & 11 & 36.6 \\
Higher Secondary & 6 & 20 \\
Graduate & 5 & 16.6 \\
Post Graduate & 2 & 6.7 \\
Total= & $\mathbf{3 0}$ & $\mathbf{1 0 0}$ \\
\hline
\end{tabular}

Table-II: Clinical and metabolic measurements of study participants before and after diet and exercise intervention for all 30 participants

\begin{tabular}{llc}
\hline $\begin{array}{l}\text { Clinical and metabolic } \\
\text { measures }\end{array}$ & $\begin{array}{c}\text { Baseline } \\
\mathbf{n}=\mathbf{3 0}\end{array}$ & $\begin{array}{c}\text { Follow-up } \\
\mathbf{n}=\mathbf{3 0}\end{array}$ \\
\hline $\begin{array}{l}\text { Fasting Glucose } \\
\text { (mmol/L) }\end{array}$ & $5.15 \pm 0.15$ & $4.80 \pm 0.11^{*}$ \\
$\begin{array}{l}\text { 2-hour glucose } \\
(\mathrm{mmol} / \mathrm{L})\end{array}$ & $9.39 \pm 0.16$ & $7.2 \pm 0.36^{*}$ \\
$\begin{array}{l}\text { Total cholesterol } \\
(\mathrm{mg} / \mathrm{dl})\end{array}$ & $179.17 \pm 5.6$ & $161.66 \pm 4.73^{*}$ \\
$\begin{array}{l}\text { HDL cholesterol } \\
(\mathrm{mg} / \mathrm{dl})\end{array}$ & $40.27 \pm 1.69$ & $38.76 \pm 1.59$ \\
$\begin{array}{l}\text { LDL cholesterol } \\
(\mathrm{mg} / \mathrm{dl})\end{array}$ & $107.43 \pm 4.73$ & $93.7 \pm 4.31^{*}$ \\
$\begin{array}{l}\text { Triglyceride (mg/d l) } \\
\text { (m) }\end{array}$ & $157.13 \pm 14.07$ & $158.93 \pm 13.01$ \\
\hline
\end{tabular}

Values are mean $\pm S E$. $p$ value reached by paired student's t-test. * indicates significant.

Table-III: Clinical and metabolic measurements of the study participants before and after diet and exercise intervention for different sex groups.

\begin{tabular}{|c|c|c|c|c|}
\hline \multirow[t]{2}{*}{$\begin{array}{l}\text { Clinical and } \\
\text { metabolic measures }\end{array}$} & \multicolumn{2}{|c|}{$\begin{array}{l}\text { Men } \\
\mathrm{n}=16\end{array}$} & \multicolumn{2}{|c|}{$\begin{array}{l}\text { Women } \\
\mathrm{n}=14\end{array}$} \\
\hline & Base line & Follow-up & Base line & Follow-up \\
\hline $\begin{array}{l}\text { Fasting glucose } \\
(\mathrm{mmol} / \mathrm{L})\end{array}$ & $5.13 \pm 0.17$ & $4.73 \pm 0.13^{*}$ & $5.17 \pm 0.26$ & $4.88 \pm 0.2$ \\
\hline $2 \mathrm{hr}$ glucose $(\mathrm{mmol} / \mathrm{L})$ & $9.34 \pm 0.2$ & $6.88 \pm 0.53^{* *}$ & $9.45 \pm 0.27$ & $7.55 \pm 0.48^{*}$ \\
\hline $\begin{array}{l}\text { Total cholesterol } \\
(\mathrm{mg} / \mathrm{dl})\end{array}$ & $178.06 \pm 7.15$ & $160.87 \pm 6.28^{*}$ & $180.42 \pm 9.07$ & $162.57 \pm 7.4^{*}$ \\
\hline $\begin{array}{l}\text { HDL cholesterol } \\
(\mathrm{mg} / \mathrm{dl})\end{array}$ & $38.56 \pm 2.18$ & $35.95 \pm 1.46$ & $42.21 \pm 2.61$ & $42.0 \pm 2.79$ \\
\hline $\begin{array}{l}\text { LDL cholesterol } \\
(\mathrm{mg} / \mathrm{dl})\end{array}$ & $105.83 \pm 4.9$ & $93.62 \pm 6.35$ & $109.24 \pm 8.65$ & $93.78 \pm 5.97$ \\
\hline $\begin{array}{l}\text { Triglycerides } \\
(\mathrm{mg} / \mathrm{dL})\end{array}$ & $168.0 \pm 18.02$ & $158.62 \pm 11.79$ & $144.71 \pm 22.26$ & $159.28 \pm 24.92$ \\
\hline
\end{tabular}

Values are mean $\pm S E$. $p$ value reached by paired student's t-test. $*$ indicates significant.
MM Haque, M Shahjahan, MS Haque et al

Figure 1A

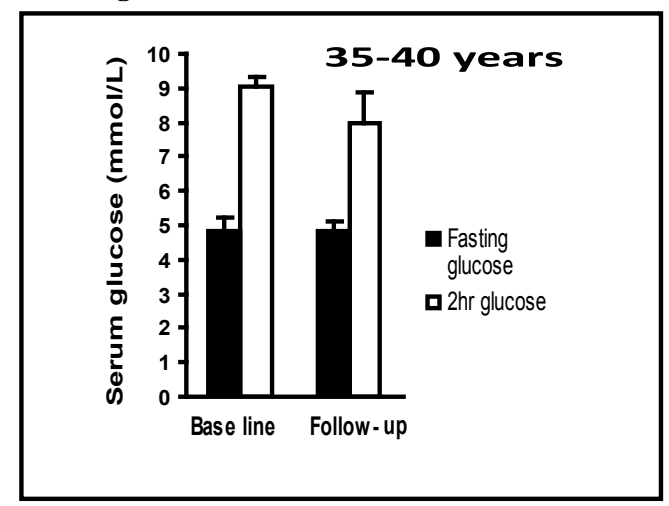

Figure 1B

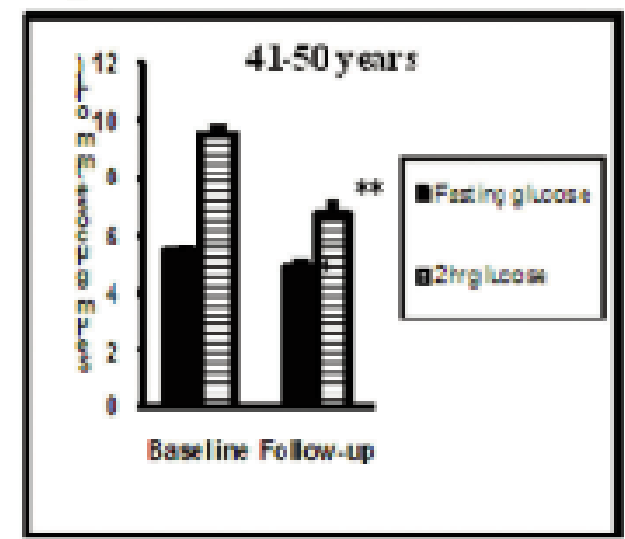

Figure 1C

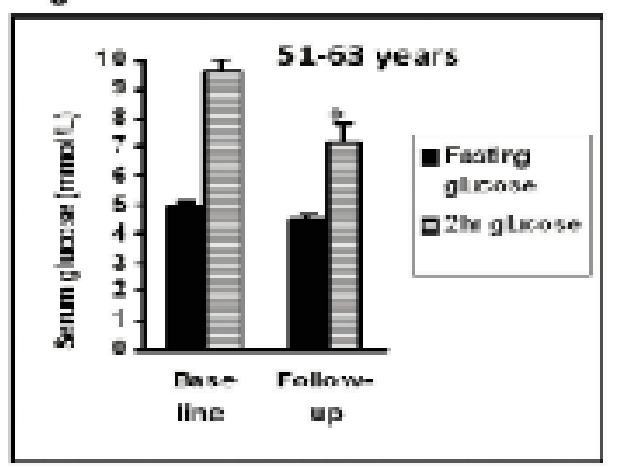

Figure-I: Fasting and 2hrs after glucose of the study participants before and after diet and exercise intervention for different age groups where 35-40 years, $n=9$ (Figure 1A), 41-50 years, $n=15$ (Figure $1 B$ ) and 51-60 years, $n=6$ (Figure 1C) were shown. Values are mean $\pm S E$. 
Effects of Diet and Exercise in Middle Aged Subjects with IGT

Table-IV: Clinical and metabolic measurements of study participants before and after diet and exercise intervention for different BMI groups

\begin{tabular}{|c|c|c|c|c|}
\hline \multirow[t]{2}{*}{$\begin{array}{l}\text { Clinical and } \\
\text { metabolic } \\
\text { measures }\end{array}$} & \multicolumn{2}{|c|}{$\begin{array}{l}\mathrm{BMI}=20-25 \mathrm{~kg} / \mathrm{m}^{2} \\
\mathrm{n}=10\end{array}$} & \multicolumn{2}{|l|}{ 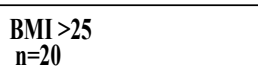 } \\
\hline & Base line & Follow-up & Base line & Follow-up \\
\hline $\begin{array}{l}\text { FastingGlucose } \\
(\mathrm{mmol} / \mathrm{L})\end{array}$ & $5.11 \pm 0.24$ & $4.47 \pm 0.18 *$ & $5.17 \pm 0.19$ & $4.83 \pm 0.14 *$ \\
\hline $\begin{array}{l}\text { 2-hour glucose } \\
(\mathrm{mmol} / \mathrm{L})\end{array}$ & $\begin{array}{l}9.36 \pm 0.21 \\
180.0 \pm 12.71\end{array}$ & $\begin{array}{l}6.83 \pm 0.75^{*} \\
160.5+7.83^{* *}\end{array}$ & $\begin{array}{l}9.41 \pm 0.22 \\
178.75 \pm 5.79\end{array}$ & $\begin{array}{l}7.38 \pm 0.40^{*} \\
162.25+6.05^{*}\end{array}$ \\
\hline$(\mathrm{mg} / \mathrm{dl})$ & $38.6 \pm 2.54$ & $36.1 \pm 2.14$ & $41.1 \pm 2.21$ & $40.1 \pm 2.10$ \\
\hline $\begin{array}{l}\text { LDL cholesterol } \\
\text { (mg/dl) }\end{array}$ & $109.7 \pm 10.79$ & $97.04 \div 8.11$ & $106.29 \pm 4.84$ & $93.77 \pm 5.82 *$ \\
\hline $\begin{array}{l}\text { Triglycerides } \\
\text { (mg) dl) }\end{array}$ & $157.8 \pm 22.04$ & $154.3 \pm 30.56$ & $156.8 \pm 18.38$ & $161.3 \pm 12.86$ \\
\hline
\end{tabular}
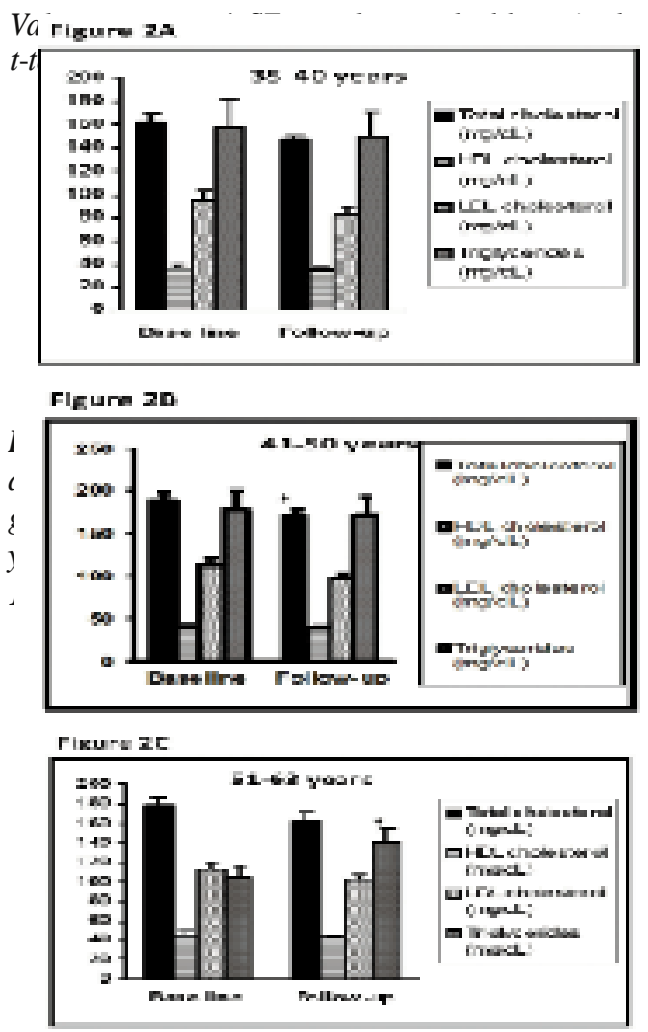

ident's

\section{Family history of diabetes}

Relevant history of diabetes in the family was found in $46.7 \%$ of participants while rest had no such history.

\section{Effects of diet and exercise intervention on blood glucose levels}

Mean fasting blood glucose for the group as a whole was recorded as $5.15 \pm 0.15 \mathrm{mmol} / \mathrm{L}$ at baseline while at 12 weeks follow-up, the value decreased significantly $(\mathrm{p}<0.05)$ to $4.8 \pm 0.11$ $\mathrm{mmol} / \mathrm{L}$ (shown in Table II). Men showed a significant decrease in mean fasting glucose values from $5.13 \pm 0.17$ at baseline to $4.73 \pm 0.13$ $\mathrm{mmol} / \mathrm{L}$ at follow-up $(\mathrm{p}<0.05)$ and women decreased their mean value from $5.17 \pm 0.26$ to $4.88 \pm 0.20 \mathrm{mmol} / \mathrm{L}$ at follow up $(\mathrm{p}=0.096)$ (Table 3). The fasting blood glucose for 35-40 yrs remained essentially unchanged at follow up $(4.82 \pm 0.39$ vs. $4.84 \pm 0.29 \mathrm{mmol} / \mathrm{L})$ while the middle (41-50 yrs) group demonstrated a highly significant decrease in fasting value from $5.44 \pm 0.14$ to $4.9 \pm 0.13 \mathrm{mmol} / \mathrm{L}$ at the followup $(\mathrm{p}<0.01)$. The blood glucose for 51-63 yrs also decreased from $4.91 \pm 0.27$ to $4.48 \pm 0.18$ $\mathrm{mmol} / \mathrm{L}$ at follow-up (not significant) (Figure $1 \mathrm{~A}, 1 \mathrm{~B}$ and $1 \mathrm{C})$. The participants with ideal weight $\left(B M I=20-25 \mathrm{~kg} / \mathrm{m}^{2}\right)$ reduced their mean value from $5.11 \pm 0.24$ to $4.47 \pm 0.18 \mathrm{mmol} / \mathrm{L}$ at follow up $(p<0.05)$. Significant decrease was also observed among the participants with $\mathrm{BMI}>25 \mathrm{~kg} / \mathrm{m}^{2}(5.17 \pm 0.19$ vs. $4.83 \pm 0.14)$ at follow-up $(\mathrm{p}<0.05)$ (shown in Table IV).

Mean 2hr blood glucose for the entire participants $(n=30)$ was reduced significantly $(\mathrm{p}<0.01)$ from the base line (at base line: $9.39 \pm 0.16$; at follow-up: $7.2 \pm 0.36 \mathrm{mmol} / \mathrm{L}$ ) (Table II). Men decreased their $2 \mathrm{hr}$ glucose value from $9.34 \pm 0.2 \mathrm{mmol} / \mathrm{L}$ at baseline to $6.88 \pm 0.53 \mathrm{mmol} / \mathrm{L}$ at follow-up $(\mathrm{p}<0.01)$, while women decreased their value from $9.45 \pm 0.27$ to $7.55 \pm 0.48 \mathrm{mmol} / \mathrm{L}$ at follow-up $(\mathrm{p}<0.05)$ (Table III). The group aged $35-40$ yrs $(\mathrm{n}=9)$ decreased their $2 \mathrm{hr}$ glucose value from $9.06 \pm 0.26$ to $7.96 \pm 0.89 \mathrm{mmol} / \mathrm{L}$ at follow-up (not significant) while the 41-50 yrs group $(n=15)$ demonstrated a highly significant reduction in $2 \mathrm{hr}$ glucose value from $9.49 \pm 0.23$ to $6.74 \pm 0.41 \mathrm{mmol} / \mathrm{L}$ at follow up $(\mathrm{p}<0.01)$. Significant fall in $2 \mathrm{hr}$ glucose value was also 
Bangladesh J Med Biochem 2014; 7(1)

observed among 51-63 yrs group $(\mathrm{n}=6)$ $(9.63 \pm 0.42$ vs. $7.2 \pm 0.65 \mathrm{mmol} / \mathrm{L}) \quad(\mathrm{p}<0.05)$ (Figure 1A, 1B and 1C). The effects of diet and exercise on blood glucose for the participants based on BMI were also examined. The participants with ideal body weight $(\mathrm{BMI}=20$ $\left.25 \mathrm{~kg} / \mathrm{m}^{2}\right)(\mathrm{n}=10)$ decreased their value from $9.36 \pm 0.21$ at baseline to $6.83 \pm 0.75 \mathrm{mmol} / \mathrm{L}$ at follow-up $(\mathrm{p}<0.05)$. Highly significant reduction in $2 \mathrm{hr}$ glucose value was observed among the participants with $\mathrm{BMI}>25 \mathrm{~kg} / \mathrm{m}^{2}$ $(\mathrm{n}=20) \quad(9.41 \pm 0.22$ vs. $7.38 \pm 0.4) \quad(\mathrm{p}<0.01)$ (Table IV).

The distributions of the study participants according to the clinical outcome at 12 weeks follow up were evaluated. Substantial improvement in glucose tolerance was observed after 12 weeks diet and exercise program. Glucose tolerance was reverted to normal in 20 participants $(66.7 \%)$, remained impaired in 08 participants $(26.7 \%)$ and deteriorated to overt clinical diabetes in 2 participants $(6.7 \%)$.

Effects of diet and exercise intervention on serum lipid levels

\section{Total cholesterol}

At the end of the 12 weeks diet and exercise program, the entire group $(n=30)$ demonstrated a significant reduction in total cholesterol level from $179.17 \pm 5.6$ at base line to $161.66 \pm 4.73$ $\mathrm{mg} / \mathrm{dL}$ at follow-up $(\mathrm{p}<0.05)$ (Table 2$)$. Men $(n=16)$ decreased their cholesterol value from $178.06 \pm 7.15$ to $160.87 \pm 6.28 \mathrm{mg} / \mathrm{dl}(\mathrm{p}<0.05)$ while women $(n=14)$ decreased their cholesterol value from $180.42 \pm 9.07$ to $162.57 \pm 7.4 \mathrm{mg} / \mathrm{dl}$ at follow-up $(\mathrm{p}<0.05)$. The differences were statistically significant for both sexes (Table III).

When the participants were grouped according to age, all three groups showed a reduction in cholesterol level at follow-up. The 35-40yrs group $(n=9)$ decreased their value from $162.22 \pm 7.95$ to $146.77 \pm 3.62 \mathrm{mg} / \mathrm{dl}$ (not significant) while the 41-50yrs group $(n=15)$ decreased their value from $189.73 \pm 8.83$ to $170.13 \pm 7.75 \mathrm{mg} / \mathrm{dl}(\mathrm{p}<0.05)$ and the 51-63 yrs group $(n=6)$ from $178.16 \pm 8.33$ to 162.83 $\pm 9.69 \mathrm{mg} / \mathrm{dl}$ (not significant). Although
MM Haque, M Shahjahan, MS Haque et al

comparable reductions in total cholesterol level were seen in all three groups, significan reduction was achieved only in 41-50 yrs group $(\mathrm{p}<0.05)$ (Figure 2A, 2B and 2C). The participants with ideal weight $(\mathrm{BMI}=20-25$ $\left.\mathrm{kg} / \mathrm{m}^{2}\right)(\mathrm{n}=10)$ reduced their mean cholesterol values from $180 \pm 12.71$ at baseline to $160.5 \pm 7.83 \mathrm{mg} / \mathrm{dL}$ at follow-up $(\mathrm{p}<0.01)$. Significant fall in total cholesterol value was also observed among the participants with $\mathrm{BMI}>25 \mathrm{~kg} / \mathrm{m}^{2} \quad(\mathrm{n}=20) \quad(178.75 \pm 5.79 \quad \mathrm{vs}$ $162.25 \pm 6.05 \mathrm{mg} / \mathrm{dl})(\mathrm{p}<0.05)($ Table IV)

\section{Triglycerides}

Table 2 shows the baseline and follow up characteristics of serum triglyceride of the study participants. The entire group $(n=30)$ demonstrated a slight increase in triglyceride level from $157.13 \pm 14.07$ at base line to $158.93 \pm 13.01 \mathrm{mg} / \mathrm{dl}$ at follow up. Although not significant, men $(n=16)$ showed a decease in triglyceride value from $168.0 \pm 18.02$ at baseline to $158.62 \pm 11.79 \mathrm{mg} / \mathrm{dL}$ at follow-up $(p=0.337)$, while the mean value increased in women from $144.71 \pm 22.26 \mathrm{mg} / \mathrm{dL}$ at base line to $159.28 \pm 24.92 \mathrm{mg} / \mathrm{dl}$ at follow-up (not significant) (Table III).

As shown in Figure 2A, 2B and 2C, there had been a fall in triglyceride values in 35-40 yrs group $(n=9)$ and also $41-50$ yrs group $(n=15)$. The 35-40 yrs group reduced the mean value from $158.33 \pm 23.24$ at baseline to $149.11 \pm 21.84$ $\mathrm{mg} / \mathrm{dl}$ at follow-up and the 41-50 yrs group also reduced their value from $178.26 \pm 22.18$ to $171.86 \pm 22.17 \mathrm{mg} / \mathrm{dl}$ at follow-up (not significant). However, a significant increased triglycerides were found only in 51-63 yrs group $(\mathrm{n}=6)$ (from $102.56 \pm 13.4$ at baseline to $141.33 \pm 12.38 \mathrm{mg} / \mathrm{dl})(\mathrm{p}<0.05)$.

The participants with ideal weight $(\mathrm{BMI}=20$ $25 \mathrm{~kg} / \mathrm{m} 2)(\mathrm{n}=10)$ showed a mild decrease in triglyceride level from $157.8 \pm 22.04$ at base line to $154.3 \pm 30.56$ at follow-up (not significant). The participants with $\mathrm{BMI}>25$ $\mathrm{kg} / \mathrm{m}^{2}$ demonstrated an increase in triglyceride value from $156.8 \pm 18.38$ to $161.3 \pm 12.86$ $\mathrm{mg} / \mathrm{dL}$ at follow-up (not significant) (Table IV). 
Effects of Diet and Exercise in Middle Aged Subjects with IGT

\section{HDL cholesterol}

Mild deterioration in mean HDL cholesterol value was observed at 12 weeks follow-up. The total group $(n=30)$ showed a decrease in mean HDL cholesterol from $40.27 \pm 1.69$ at baseline to $38.76 \pm 1.59 \mathrm{mg} / \mathrm{dl}$ at follow-up (Table II). Men decreased their mean value from $38.56 \pm 2.18$ to $35.95 \pm 1.46 \mathrm{mg} / \mathrm{dl}$ (not significant), while mean value in women was remained essentially unchanged at follow-up $42.21 \pm 2.61$ vs. $42.0 \pm 2.79$ (not significant) (Table III).When the participants were grouped according to age, they showed a slight decrease (not significant) in cholesterol level at follow-up (Figure 2A, 2B and 2C). The 35-40 yrs group showed their value from $36.33 \pm 2.68$ at base line to $35 \pm 1.68 \mathrm{mg} / \mathrm{dl}$ at follow-up (not significant). In 41-50 yrs group, the mean values are $40.73 \pm 2.51 \mathrm{mg} / \mathrm{dl}$ at baseline and $39.67 \pm 2.73 \mathrm{mg} / \mathrm{dl}$ at follow-up (not significant) while 51-63 yrs group $(n=6)$ showed their value from $45 \pm 3.48 \mathrm{mg} / \mathrm{dl}$ at baseline to $42.17 \pm 2.76 \mathrm{mg} / \mathrm{dl}$ at follow-up. Although not significant, greater decline in HDL cholesterol was observed in participants with ideal body weight $(B M I=20-25 \mathrm{~kg} / \mathrm{m} 2)(38.6 \pm 2.54$ vs. $36.1 \pm 2.14)$ than the participants with $\mathrm{BMI}>25$ $\mathrm{kg} / \mathrm{m} 2(41.1 \pm 2.21$ vs. $40.1 \pm 2.1)$ (Table IV). The results demonstrate that dietary manipulation and physical exercise are partially involved in lowering of HDL cholesterol for IGT patients.

\section{LDL cholesterol}

As shown in Table II, total group as a whole $(\mathrm{n}=30)$ showed a significant reduction in LDL cholesterol value from $107.43 \pm 4.73 \mathrm{mg} / \mathrm{dl}$ at base line to $93.7 \pm 4.31 \mathrm{mg} / \mathrm{dl}$ at follow-up $(\mathrm{p}<0.05)$. Men $(\mathrm{n}=16)$ decreased their mean value from $105.83 \pm 4.9$ to $93.62 \pm 6.35 \mathrm{mg} / \mathrm{dl}$ (not significant) and women $(\mathrm{n}=14)$ reduced their value from $109.24 \pm 8.65$ to $93.78 \pm 5.97$ $\mathrm{mg} / \mathrm{dl}$ (not significant) (Table 3 ). The $35-40 \mathrm{yrs}$ group $(\mathrm{n}=9)$ reduced their value from $94.22 \pm 8.34$ to $82.28 \pm 6.59 \mathrm{mg} / \mathrm{dl}$ at follow-up (not significant). In 41-50 yrs group $(n=15)$, mean value decreased from $113.25 \pm 7.11 \mathrm{mg} / \mathrm{dl}$ at baseline to $97.2 \pm 6.94 \mathrm{mg} / \mathrm{dl}$ at follow-up (not significant) and 51-63 yrs group $(n=6)$ also decreased their value from $112.66 \pm 7.31 \mathrm{mg} / \mathrm{dl}$ at baseline to $102.06 \pm 6.17 \mathrm{mg} / \mathrm{dl}$ at follow-up (not significant) (Figure 2A, 2B and 2C). The participants with ideal body weight $(\mathrm{BMI}=20$ $\left.25 \mathrm{~kg} / \mathrm{m}^{2}\right) \quad(\mathrm{n}=10)$ reduced their LDL cholesterol value from $109.7 \pm 10.79$ to $97.04 \pm 8.11 \mathrm{mg} / \mathrm{dl}$ at follow-up and the participants with $\mathrm{BMI}>25 \mathrm{~kg} / \mathrm{m}^{2}(\mathrm{n}=20)$ had a significant fall in LDL cholesterol value at follow-up $(106.29 \pm 4.84$ vs. $93.77 \pm 5.82)$ $(\mathrm{p}<0.05)($ Table IV)

\section{Discussion}

The present study was conducted to determine the influence of dietary modification and physical exercise in Bangladeshi subjects with impaired glucose tolerance. The most important aspect of the present study was that a group of middle aged (mostly sedentary and over-weight) glucose intolerant subjects successfully participated in a 12 weeks diet and exercise intervention program, with a dropout rate less than $10 \%$. During the 12 weeks period, majority of the participants were able to make their life style changes and achieved the recommended dietary intake and physical activities. Mean age of the total participants was recorded 45 years with a range of 35-63 years. $50 \%$ of the total participants aged 41-50 years, $30 \%$ aged $35-40$ years and rest $20 \%$ was between 51-63 years. These findings support the view that age is an important determinant of the course of the impaired glucose tolerance and the risk of T2DM increases with age ${ }^{2}$. The preponderance of the middle class subjects could be attributed to fact that rapid changes in life style are more marked among this group of people.

At the end of 12 weeks diet and exercise program a significant reduction in blood glucose (both fasting and $2 \mathrm{hr}$ post load glucose) was achieved in the participants. The results were consistent with other previous studies 14,15 , however, it was probably due to the cumulative effect of both dietary modification and increase in physical activities on glucose metabolism. The effectiveness of high complex 
Bangladesh J Med Biochem 2014; 7(1)

carbohydrate, high fiber and low fat diet has been documented in many short and long-term studies16,17. Calorie restriction and weight loss have been shown to be effective in amelioration of glucose intolerance. Previous studies have shown that a single bout of exercise can increase insulin receptor sensitivity ${ }^{18}$, in addition, some evidence suggests that regular exercise training increases the number of insulin receptors and improves glucose tolerance ${ }^{18 .}$

In our study, we found that mean fasting glucose decreased both in men and women, however the result appeared to be significant for men and also there had been a significant reduction in $2 \mathrm{hr}$-post load glucose value in both men and women at the end of 12 weeks intervention. Therefore, the intervention program was beneficial to both men and women. The differences in the level of significance for men and women could be attributed to the ability to participate in physical exercise and were essentially comparable in these two groups. Outdoor sports and activities are generally less accessible to women which can not be ignored and needs further evaluation. As age was concerned, diet and exercise intervention failed to exert a significant influence in younger participants (35-40 yrs). FBG remained almost unchanged and $2 \mathrm{hPG}$ value did not reach the level of significance at follow-up. However, the 41-50 yrs group was benefited much from diet and exercise program. Highly significant decline in FBG and $2 \mathrm{hPG}$ were achieved in this group. Although both FBG and $2 \mathrm{hPG}$ values were decreased in older participants (51-63 yrs), only the reduction in $2 \mathrm{hPG}$ value reached the level of significance ( $\mathrm{P}$ $<0.05)$.

Mean total cholesterol value for the entire participants was recorded $189.17 \quad 5.6 \mathrm{mg} / \mathrm{dl}$ with a range of $120-270 \mathrm{mg} / \mathrm{dl}$ at base line. $86.7 \%$ of the total participants had cholesterol level within normal range $(<200 \mathrm{mg} / \mathrm{dl})$. Only four subjects $(13.3 \%)$ had cholesterol level $>200 \mathrm{mg} / \mathrm{dl}$. These findings suggest that hypercholesterolemia may not be an association of impaired glucose tolerance. Our view
MM Haque, M Shahjahan, MS Haque et al

contradict the report of a previous study ${ }^{19}$ which indicated that the pre-diabetic individuals have increased cholesterol, triglycerides, glucose concentration and decreased HDL cholesterol concentration, however at the end of 12 weeks diet and exercise intervention, the total participants demonstrated a significant reduction in mean total cholesterol. The result of the present study was consistent with others ${ }^{14,20}$. The decrease in mean total cholesterol was almost identical in both men and women and was observed both in participants with ideal body weight $\left(\mathrm{BMI}=20-25 \mathrm{~kg} / \mathrm{m}^{2}\right)$ and in participants with $\mathrm{BMI}>25 \mathrm{~kg} / \mathrm{m}^{2}$.

Mean triglycerides were recorded as 157.13 $\mathrm{mg} / \mathrm{dL}$ at baseline and majority of the participants $(66.7 \%)$ had triglycerides level within normal range, only $33.3 \%$ of the participants had hypertriglyceridemia $(>165$ $\mathrm{mg} / \mathrm{dl}$ ). These findings suggest that hypertrigl yceridemia was not a strong association for impaired glucose tolerance. Contrary to the findings reported from other studies 21,22 , there had been a slight increase in mean triglycerides value at the end of 12 weeks. Modest but nonsignificant decline was observed among 3540 yrs and 41-50 yrs groups while older (51-63) group demonstrated a significant increase in triglycerides at follow-up. The results showed that the diet and exercise intervention had failed to exert a favorable influence on triglycerides level over a period of 12 weeks in the participants, however further studies of longer duration are needed to evaluate its effectiveness.

In contrast to findings in other previous studies $^{23}$, mild deterioration in HDL cholesterol value was observed at follow-up. Although not significant, greater decline was observed in participants with ideal body weight $(\mathrm{BMI}=20$ $25 \mathrm{~kg} / \mathrm{m}^{2}$ ). Similar findings were reported in some studies 24 which showed that in addition to reduction in total cholesterol, high carbohydrate, high fiber and low fat diet could also reduce HDL cholesterol under isoenergetic condition. Moreover, diet reduced in total fat and saturated fatty acids often has been shown to reduce the HDL cholesterol concentration if not 
Effects of Diet and Exercise in Middle Aged Subjects with IGT accompanied by weight loss 25 . Verginia et al. 25 also reported that 12 weeks of exercise training without substantial weight loss did not alter the diet related decrease in HDL cholesterol in older individuals with impaired glucose tolerance. The entire group demonstrated a significant reduction in LDL cholesterol at follow-up and the greater decline was observed in women. Participants with $\mathrm{BMI}>25 \mathrm{~kg} / \mathrm{m}^{2}$ demonstrated a significant decrease in LDL cholesterol,while the participants with ideal body weight did not show similar effects. Significant reduction in LDL cholesterol achieved at follow up could be correlated with the studies ${ }^{26,25}$. The increased dietary manipulation and regular physical exercise might be involved in lowering LDL cholesterol through cellular utilization process.

In conclusion dietary modification in combination with regular physical exercise appeared to be highly effective for improving glucose tolerance, lowering total cholesterol and LDL cholesterol in the subjects over a short period of time. It is of particular interest that participants aged 41-50 years were benefited much from this diet and exercise intervention program than the younger age group $<41$ year and the older groups $>50$ years. Our study suggests that people with IGT who are able to receive individualized advice and encouragement can make and sustain lifestyle change which result in improvements in glucose tolerance. It is likely that these changes could result in a decrease or delay in the progression of IGT to diabetes.

\section{Acknowledgements}

This research was financially supported by Bangladesh Medical Research Council, Dhaka. In particular, we thank Ms. Shamima Sultana for her help in data analysis. We wish to thank all doctors, officers and staffs of diabetic association, Rajshahi for their co-operation and technical assistance.

\section{References}

1. Mayfield J. Diagnosis and classification of diabetes mellitus: New criteria. Am Fam Physician 1998; 58: $1355-1362$.

2. Saad MF, Knowler WC, Pettitt DJ, Nelson RG, Bennett PH. The natural history of impaired glucose tolerance in the Pima Indians. N Engl $\mathbf{J}$ Med 1988; 319: 1500-1506.

3. Uusitupa MI. Early life style intervention in patients with non-insulin dependent diabetes mellitus and impaired glucose tolerance. Annals of Medicine 1996; 28: 445-9.

4. Savage PJ, Bennion LJ, Flock EV, Nagulesparan M, Mott D, Roth J, Unger RH, Bennett PH. Dietinduced improvement of abnormalities in insulin and glucagon secretion and in insulin receptor binding in diabetes mellitus. J Clin End Metab 1979; 48: 999-1007.

5. Mann JI. Lines to legumes: changing concepts of diabetic diets. Diabet Med 1984; 1: 1991-198.

6. Reitman JS, Vasquez B, Klimes I, Nagulesparan M. Improvement of glucose homeostasis after exercise training in non insulin dependent diabetes. Diabetes Care 1984; 7: 434-441.

7. Schneider SH, Amorosa LF, Khachadurian , Ruderman NB. Studies on the mechanism of improved glucose control during regular exercise in type 2 (non-insulin dependent diabetes). Diabetologia 1984; 26: 355-60.

8. Koivisto VA, Yki-Jarvinen H, DeFronzo RA. Physical training and insulin sensitivity. Diabet Metabol Rev 1986; 1: 445-81.

9. Trinder P. Determination of glucose in blood using glucose oxidase with an alternative oxygen acceptor. Ann Clin Biochem 1969; 6: 24-25.

10. Richmond W. Preparation and properties of a cholesterol oxidase from Norcardia spp. and its application to the enzymatic assay of total cholesterol in serum. Clin Chem 1973; 19: 1350-1356.

11. Jacobs NJ, Van Demark PJ. The purification and properties of the -glycerophosphate oxidizing enzyme of streptococcus faecalis $10 \mathrm{Cl}$. Arch Biochem Biophys 1960; 88: 250-255.

12. Burstein M, Scholnick HR, Morphin R. Rapid method for the isolation of lipoproteins from human serum by precipitation with polyanions. $\mathbf{J}$ Lipid Res 1970; 11: 583-95. 
13. Friedewald WT, Levy RL, Fredrickson DS. Estimation of the concentration of low density lipoprotein cholesterol in plasma without use of the preparative ultracentrifuge. Clin Chem 1972; 18: 499-502.

14. Barnard RJ, Lattimore L, Holly RG, Cherny S, Pritikin N. Response of non insulin dependent diabetic patient to an intensive program of diet and exercise. Diabetes Care 1982; 5: 370-4.

15. Eriksson KF, Lindgrade F. Prevention of type 2 (non-insulin dependent) diabetes mellitus by diet and physical exercise. The 6 years Malmo Feasibility study. Diabetologia 1991; 34: 891-8.

16. Kiehm TG, Anderson JW, Ward K. Beneficial effects of a high carbohydrate, high fiber diet in hyperglycemic men. Am J Clin Nutr 1976; 29: 895-99.

17. Jenkins DJA, Wolever TMS, Bacon S, Nineham R, Lees R, Rowden R, Love M, Hockaday TDR. Diabetic diets, high carbohydrate combined with high fiber. Am J Clin Nutr 1980; 33: 1729-33.

18. Koivisto VA, Soman V, Conrad P, Hendler R, Nadel E, Felig P. Insulin binding to monocytes in trained athlete. J Clin Invest 1979; 64: 1011-15.

19. Haffner SM, Stern MP, Hazuda HP, Mitchell BD, Patterson JK. Cardiovascular risk factors in confirmed pre-diabetics: does the clock for coronary heart disease start ticking before the onset of clinical diabetes. JAMA 1990; 263: 2893-8.

20. Page RCL, Harnden KE, Cook JTE, Turner RC. Can life style of subjects with impaired glucose tolerance be changed? A feasibility study. Diabet Med 1992; 9: 562-6.
21. Shorey RL, Sewell B, Brein M. Efficacy of diet and exercise in the reduction of serum cholesterol and triglyceride in free living adult male. Am $\mathbf{J}$ Clin Nutr 1976; 29: 512-521.

22. Hall Y, Stamler J, Cohen PB, Monjonnier L, Epstein MB, Berkson DM, Whipple IT, Catchings S. Effectiveness of a low saturated fat, low cholesterol, weight reducing diet for the control of hypertriglyceridemia. Atherosclerosis 1972; 16: 389-403.

23. Tran ZV, Weltman A. Differential effect of exercise on serum lipid and lipoprotein levels seen with changes in body weight. JAMA 1985; 254 : 919-24.

24. Clevidence BA, Judd JT, Schatzkin A, Muesing RA, Campbell WS, Brown CC, Taylor PR. Plasma lipid and lipoprotein concentration of men consuming a low fat, high fiber diet. Am J Clin Nutr 1992; 55: 689-94.

25. Verginia AH, Fiatarone MA, Ferrara CM, Mcklamara JR, Charnley JM, Evanj WJ. Lipoprotein response to exercise training and a low fat diet in older subjects with glucose intolerance. Am J Clin Nutr 1994; 59: 820-6.

26. Sacks F, Handysides G, Marais G, Rosner R, Kass E. Effect of low fat diet on plasma lipoprotein levels. Arch Intern Med 1986; 146: 1573-7. 